This item was submitted to Loughborough's Research Repository by the author.

Items in Figshare are protected by copyright, with all rights reserved, unless otherwise indicated.

\title{
Devolution and national identity: the rules of English (dis)engagement
}

PLEASE CITE THE PUBLISHED VERSION

http://dx.doi.org/10.1111/j.1469-8129.2010.00441.x

PUBLISHER

() The authors. Journal compilation @ ASEN/Blackwell Publishing Ltd

VERSION

AM (Accepted Manuscript)

LICENCE

CC BY-NC-ND 4.0

REPOSITORY RECORD

Condor, Susan. 2019. "Devolution and National Identity: The Rules of English (dis)engagement". figshare. https://hdl.handle.net/2134/15244. 
This item was submitted to Loughborough's Institutional Repository (https://dspace.lboro.ac.uk/) by the author and is made available under the following Creative Commons Licence conditions.

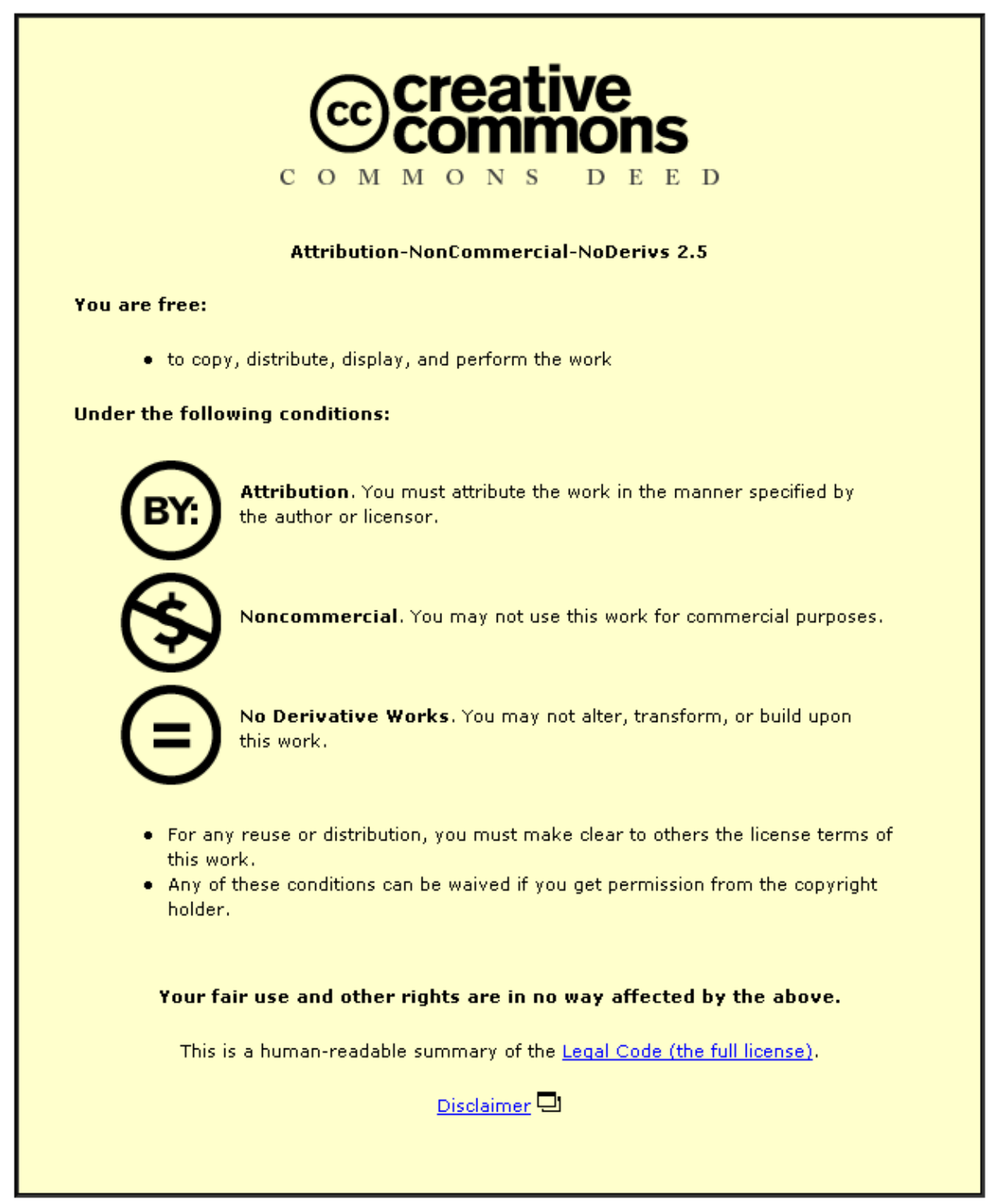

For the full text of this licence, please go to: http://creativecommons.org/licenses/by-nc-nd/2.5/ 
Devolution and National Identity:

The Rules of English Disengagement.

Susan Condor,

Lancaster University.

Word count: 8091

Nations and Nationalism 16 (3), 2010, 525-543. 


\begin{abstract}
.
In this paper I consider why the expected English backlash to the asymmetric UK devolution settlement has not yet materialised. Using a corpus of conversational interviews, I discuss the various ways in which people in England currently understand the relationship between national identity and political entitlement. I conclude that English political quiescence, far from constituting an enigma, is comprehensible in the light of the fact that members of the general public do not normally base assessments of political legitimacy on calculations of English national self-interest defined in contrast to Scotland. Rather, political issues tend to be judged on the bases of equity and procedural justice. English identity is rarely considered legitimate grounds for political voice. Rather, most people evidence a concern to balance a recognition of Scottish rights to national self-determination with an endorsement of the normative requirements of public reason, civility and civic responsibility incumbent upon the English majority.
\end{abstract}


The enigma of the missing English backlash.

A decade ago, debates concerning the establishment of the Scottish Parliament were accompanied by a series of moral panics concerning what, at the time, appeared would be the inevitable response of the population of England. The Earl of Onslow summed up the concerns of many when, during the second reading of the Scotland Bill in the House of Lords in June 1998, he stated categorically that, 'The English simply will not put up with it’.

Pundits differed on the finer details of the impeding crisis. For some, the English would be galvanised into action once they realised that the 'break up of Britain' threatened their cherished sense of British identity. Others predicted that the English public would mobilise around more pragmatic concerns relating to their country's fiscal disadvantage, or the fact that the asymmetric character of the political settlement had resulted in a relative democratic deficit for the population of England (see Bryant, 2008). These differences in focus aside, commentators generally adopted a similar conjectural schema: The fact that the component nations of the UK were not being treated equivalently would provoke resentment which would, in turn, inevitably lead to conflict. This kind of stance can be illustrated by an extract from Lord Ellenborough's contribution to the Lords' debate on the Scotland Billi:

There is no point in bringing forward proposals that are not fair to all concerned--and the proposals are not fair to England. The English not only expect fairness but are just as entitled as the Scots, Welsh and Irish to express their national identity. The irresponsible weakness of the Bill is that it builds up potential conflict between Scotland and England.

According to this account, the fundamental problem with the Scotland Bill was that it did not allow English people equal rights to political expression of their national identity. In contrast, other commentators, especially those from England, argued that 
the irresponsible weakness of the Bill rested precisely on the fact that it would encourage people in England to express their national identity in political terms:

The Government need to make up their mind what they think they are doing. Is their devolution policy based on regionalism or nationalism? If I understand the Bill correctly, I must conclude that the Government are acting on a sense of Scottish national self-identity. If that is so, the Bill is about nationalism, which is why I worry about the reawakening of English nationalism.

On whatever concept the Bill is based, the Government simply have to treat the other three parts of the United Kingdom in exactly the same way, because if they do not, as others have said before me, they will provoke an English backlash. Indeed, I get the impression that that backlash has already begun.

Far too many people seem to have forgotten what English nationalism is capable of. Even the briefest scanning of the history of the United Kingdom should be enough to remind us all: rape, pillage and mayhem leap from virtually every page of that history. Throughout Scotland, Wales and Ireland there are countless monuments to the local heroes who were slain in a vain attempt to stem a relentless tide of English domination. It is worth looking back at what history has to teach us.

[David Wilshire MP, Commons Second Reading of the Scotland Bill ${ }^{\mathrm{ii}}$ ]

Having been promised mob rule, carnage, pillage and mayhem, the actual reaction of the population of England to the establishment of the Scottish Parliament proved something of an anticlimax. A relatively small number of people mobilised through organizations such as the Campaign for an English Parliament, but the majority appeared disinclined to engage in any formal political response. Regular British Social Attitudes surveys found little evidence of general resentment (Curtice, 2003; Curtice \& Heath, 2000; Curtice \& Seyd, 2001; Curtice \& Sandford, 2004), and 
relatively low levels of popular support for the establishment of an English Parliament or the development of English regional governance (e.g. Heath, Rothon \& Jarvis, 2002). As Aughey (2007) summarised the situation, 'The impression (so far) is not one of simmering outrage but one of national equanimity' (p. 198). Contrary to the Earl of Onslow's confident prediction, the English appeared to have simply put up with it.

\section{Crisis? What crisis?}

In this article, I shall be considering why the resentful English backlash, predicted so confidently a decade ago, has not materialised. Interestingly, this question has rarely been asked. Survey researchers are generally content to note that the asymmetric settlement apparently reflects the 'settled will of the English people' (e.g. Bogdanor, 2005; Curtice \& Seyd, 2001), sometimes casting this as a curious enigma, 'people in England may accept the principle of asymmetric devolution ... strangely, people in England do not appear to be particularly keen on devolution for themselves’ Curtice (2006 p. 104, my emphasis).

On the rare occasions when commentators have attempted to explain this unanticipated state of affairs, they have been disinclined to consider the possibility that the original forecasts might have been built upon false premises. Rather, they typically resort to speculative assertions concerning pathologies of English national character. Two kinds of account predominate. First are those that attribute the absence of English political response to apathy: a moral or motivational failure, often seen to be the product of arrogance, complacency or lethargy. As the political commentator Andrew Marr ${ }^{\mathrm{iii}}$ put it:

'You hear people yelling about some looming crisis. What do you do?

You sit back, sip your cooling tea and don’t bother your fat backside. 
How else can we explain the utter lack of interest in the possibility of the breakup of Britain, at least as far as the English majority is concerned?’

‘Apathy' is a convenient construct for explaining away any form of political inaction. However, whether this can provide an adequate explanation for English political quiescence in the aftermath of UK devolution is questionable. Political scientists have certainly interpreted the tendency for people in England to respond to survey questions concerning devolution using the ‘don’t know’ option and avoiding the ‘strongly agree/disagree' response categories, as prima facie evidence of English 'indifference’ (Curtice \& Sandford, 2004). However these same response styles can also be used to convey ambivalence, a strongly held middle-of-the-road attitude, or employed when the respondent does not understand the question. In addition, any explanation of political quiescence needs to be able to distinguish between situations in which people are passively detached from current public debates, and those in which political disengagement is actively motivated by concerns over civil etiquette and democratic respect (Condor \& Gibson, 2006; Eliasoph, 1998).

A second form of explanation focuses on a supposed cognitive deficiency of the English public. Specifically, it is suggested that people in England have somehow failed to recognize their identity, and hence their distinctive interests, as English. These arguments draw upon widely available stereotypes to the effect that people in England do not know the difference between Englishness and Britishness (cf. Condor, 2006; Condor \& Abell, 2006), or that they simply lack any sense of national identity (cf. Aughey, 2007). Once again, this line of argument is rather short on substantiating evidence. In the first place, survey researchers have found little statistical relationship in England between individual respondents' reports of their sense of national identity and their constitutional preferences (Curtice \& Seyd, 2001). More generally, the 
presumption that people in England suffer from a collective deficiency of national identity often stems from an overly literal interpretation of questionnaire and interview responses. Forms of behaviour that are typically interpreted as evidence of English lack of, or indifference to, national identity (such as verbal identity-denials, attempts to mitigate identity claims, or a disinclination to engage in debates about whether they see themselves as English-or-British) may often in fact represent civility devices, designed to display modesty, interpersonal sensitivity and responsible citizenship (Condor, 1996; 2006; Condor \& Abell, 2006).

Finally, as an explanation of political quiescence, identity-deficit explanations often appear to rest upon a rather dubious form of syllogistic reasoning: Since political action may be promoted by national identity, it therefore follows that inaction must be due to an absence of national identity. This line of argument overlooks the possibility that policy preferences could ever be motivated by concerns other than those of perceived national group self-interest. In addition, it rests upon the tacit presumption that the only way in which national identity may be manifested politically is through the 'rational' pursuit of national self-interest.

\section{Commonsense Political Reasoning in England.}

In the process of discussing the response of the population of England to devolved governance, politicians and public opinion researchers have tended to invoke objectified, categorical, images of The English. In this article I will attempt at least partially to turn the representational tables, and consider what, if anything, The English have to say for and about themselves. Specifically, I shall consider how analyses of ordinary people’s vernacular political reasoning might usefully supplement survey research on public opinion. 
In this article I shall be drawing on an extensive body of conversational interview data collected in England between 2000-9. The interviews were either conducted on a one-to-one basis, or else took the form of prompted discussions between groups of friends or family members. The people who took part in the research were recruited with a view to maximizing the diversity of the sample in terms of region of origin and residence, age, gender, ethnicity, political affiliation, educational qualifications and political and civic engagement.

Details of the procedure used to collect and to analyse the corpus of interviews have been reported elsewhere (REFERENCE WITHHELD). For present purposes, two particular issues are worth emphasising. First, this data set is relatively large by the standards of qualitative research, currently comprising 1652 transcripts ${ }^{\text {iv }}$. Second, the interviews were designed to tap the types of vocabulary and lines of argument that people might use in their everyday lives. Potential participants were informed simply that the research concerned 'how people feel about the places they live'. The interviews generally took the form of sociable encounters (sometimes described as 'chats') that took place in informal locales such as public houses, parks, coffee shops, or in the respondents' homes. Respondents were initially encouraged to speak freely about their family history, experiences of mobility and travel, local community and political involvement. In cases where the respondent's own narrative led them to spontaneously mention issues relating to national identity and devolved governance, the interviewers restricted their contribution to general prompts. In cases where the interviewers resorted to actively shaping the direction of the conversation, they only started to do so after it was clear that the respondent was entirely relaxed and was conversing in an unselfconscious fashion. 
Some of the interviews were conducted as part of a panel study designed to analyse transformations in popular understandings of national identity and citizenship in the immediate aftermath of the establishment of the Scottish Parliament ${ }^{\mathrm{v}}$. In practice, however, the kinds of argument that people in England employ when discussing the process of devolved governance has remained remarkably stable over time. This is true both at the level of the population and at the level of the individual (REFERENCE WITHHELD).

In his account of the advantages of conversational interviewing for mapping everyday political reasoning, Lane (1962, p. 9) emphasised how this technique may provide 'insight into connotative meanings of words or phrases', enabling the analyst to 'follow the course of associative thinking' and to appreciate 'the mechanisms of argument and evasion employed with sensitive political material'. In the following pages I shall start out by briefly noting some common features of the interview accounts. I shall then go on to distinguish four different types of argument that respondents could use when discussing the legitimacy of devolved governance and formulating views concerning the relationship between national identity and political entitlement.

Common Features in English Accounts of Devolution.

\section{Perceived situational relevance of English national identity.}

In view of the heterogeneous character of the sample it was hardly surprising that respondents differed in the ways in which they described their own sense of national identity. In addition, it was apparent that the same individual's account of their sense of national identity could vary according to rhetorical context. However, in the course of discussing devolution, all respondents spontaneously adopted an English national footing, often contrasting an English we and here with a Scottish them and 
there. This tendency was apparent even among people who in other contexts refused to position themselves in national terms, and among those from minority ethnic backgrounds who consistently claimed never to regard themselves as English.

\section{Lack of specific knowledge concerning the devolution process.}

Respondents generally displayed a basic awareness of UK constitutional reform in so far as the vast majority were at least aware of the existence of the Scottish Parliament. However, very few possessed detailed information about the devolution process, and few displayed any meaningful awareness of debates concerning the prospect of English regional governance. Significantly, respondents were also generally unaware of those particular issues that political scientists predicted might constitute a ‘source of tension’ (Curtice \& Seyd, 2001 p. 230). For example, there was little evidence that people knew much about the fiscal relationship between Scotland and England. When respondents did mention fiscal matters, many assumed that the population of Scotland was disadvantaged in terms of public expenditure and that policies initiated by the Scottish Parliament had been financed by taxes levied in Scotland. On the relatively rare occasions that people recognized that the population of Scotland enjoyed a higher share of UK public expenditure than the population of England, they tended to assume that this had been determined on a calculation of relative need, and was therefore a fair arrangement.

\section{Distinctions between attitude objects.}

Summaries of survey data often gloss questions concerning various policy issues pertaining to UK constitutional change in generic terms (for example, as 'attitudes towards the principle of asymmetric devolution'). However, respondents' conversational interview accounts were often more nuanced than these kinds of formulations allow. In particular, people often spontaneously distinguished between 
their attitudes towards the Scottish Parliament and their attitudes towards devolution as a general political principle. In addition, respondents were inclined to distinguish their views on devolution and/or the Scottish Parliament from their opinions about more specific issues. For example, respondents who displayed awareness of the West Lothian Question (relating to the ability of Westminster MPs representing constituencies in Scotland to vote on legislation pertaining only to England) generally expressed the view that the situation was unfair. However, they did not typically treat this consideration as relevant to their general assessment of the legitimacy of the devolution process.

\section{English interests not calculated through comparison with Scotland.}

As we have seen, elite predictions concerning an impending English backlash generally presumed that resentment would arise once people in England recognized that Scotland and England were not being treated in 'exactly the same way'. However, from the interview accounts it was clear that that people were not inclined to evaluate their national interests in direct comparison to Scotland. Respondents tended overwhelmingly to employ historical (past-present) rather than international (England-Scotland) comparisons. Consequently, people were typically inclined towards the view that, since the governance of Scotland has 'always' been 'different', and since devolution had not changed the governance of England, the situation for England has not materially changed.

\section{Devolution understood as a matter of political rights.}

Predictions that the establishment of the Scottish Parliament would fuel resentment among the population of England tended to be predicated on the assumption that people would inevitably evaluate the new political status quo in terms of its substantive outcomes. In practice, however, the interview respondents rarely 
employed this kind of logic. Rather, respondents’ discussions of the Scottish Parliament typically involved appeals to abstract principles of procedural justice. Specifically, the establishment of the Parliament was generally understood to be fair in so far as it reflected the rights of Scottish people to political self-determination. This perspective was summed up by the popular cliché, often used in discussions of devolved governance: 'if that's what they want':

I So what were your views on the Scottish Parliament?

JM Good for them, if that's what they want.

I In what ways do you think that having a separate parliament will be good for Scotland?

JM Well, I'm not actually sure that it is that good for Scotland ((laugh)) But it's not up to me is it? They had a referendum and that's what they voted for.

The tendency for assessments of the Scottish Parliament to focus on matters of rights and of procedural justice also meant that respondents typically did not regard the substantive outcome for England to be relevant factor when calculating the legitimacy of the new constitutional arrangements:

KG I'm not sure if it's good for England. But it's fair. If that's what they want and what they voted for then I think they should have their own parliament. But I'm not sure how it's going to pan out for England, whether England will lose out in any way. I don’t know.

In view of predictions that the asymmetric character of the devolution settlement would provoke an English backlash against Scotland, it was interesting to note that, on the rare occasions that respondents did voice any resentment concerning the 
consequences of devolution for their own country, they typically attributed blame to the British Government rather than to the Scottish People.

As we shall see shortly, rights-based arguments could take a variety of forms, and respondents in particular disagreed about the extent to which rights-based arguments should be applied to England. However, the common view that the Scottish Parliament reflected the settled will of the Scottish people often led people to suggest that the population of England was not entitled to object, or even to express views on the subject:

I Do you think Scotland should have its own parliament [...] do you agree with it?

DP Dunno. That's actually down to the people of the country. I Mm.

DP That's not for us to decide. That's for them to decide.

I Well, for you on your English side of the fence, what do you think?

DP Oh I can’t answer that.

Since 2007 respondents in England have been increasingly inclined to endorse the prospect of Scottish independence in so far as they now commonly understand this, also, to represent the settled will of the Scottish people.

Frames of Reference in Accounts of Devolution.

Although survey researchers often represent their findings in terms of a single national Public Opinion, it is hardly surprising that in the context of conversationalstyle interviews and informal group discussions, people from England could employ a range of different arguments about UK constitutional change. In the interests of clarity of exposition, I will summarize these positions in terms of four distinct clusters of views $^{\mathrm{vi}}$, which I shall term, Popular Nationalism; Localism; Reasonable 
Pragmatism, and Liberal Cosmopolitanism $^{\text {vii }}$. Of these various types of account, only one (Popular Nationalism) involved the respondent adopting a particular claim to national self-identity. All of the other frames of reference could accommodate respondents variously claiming a strong, moderate or weak sense of identity as English, British, both or neither. However, this is not to say that people generally treated national identity as irrelevant to devolved governance. On the contrary, each of these constellations of opinion tended to be associated with a particular understanding of the implications of English nationality for political voice ${ }^{\text {viii }}$.

\section{Popular Nationalism.}

Arguments classed as examples of Popular Nationalism tended to be used by respondents with relatively high levels of general political awareness and relatively high levels of domain-specific knowledge concerning the process of devolution. These respondents typically claimed right-wing political views, and were often affiliated with non-mainstream political parties.

This cluster of opinions was characterised by a combination of two distinctive features. First was the explicit invocation of an ethnic conceptualization of nationhood in conjunction with the endorsement of political Nationalism as an abstract principle. This stance was reflected, amongst other things, by the respondent displaying concern over the distinction between England and Britain (including a tendency to self-categorize as ‘English not British’), and voicing opposition to multiculturalism and EU integration.

The second distinctive feature involved the adoption of what Kazin (1998) terms the 'language of popularism'. This entailed the respondent treating their avowals of English identity as claims to commonality with other 'ordinary' English people. Typically, this also involved the respondent adopting the stance of speaking 
‘up’ for The English against existing agents and structures of state power, and against a dominant liberal value system. These arguments generally had a redemptive quality, pointing towards a utopian future when English national identity, currently suppressed by the British State, would be granted open political expression.

Speakers employing the discourse of Popular Nationalism typically adopted a 'rational' position in Rawls's (1996) sense, in that they treated the accomplishment of national self-determination as an ultimate political good. Respondents often expressed strong support for the Scottish Parliament in so far as it could be regarded as the first step towards eventual independence for the component nations of the UK:

AD Scotland and England, I mean it's two separate countries, int'it? I Yeah.

AD So why haven't they got a right to, if it's two separate countries? Why should we have this political correctness all one Great Britain. I mean, it's their choice. If the Scottish people want to rule themselves then they should. They are proud of being Scottish and good on them. And the English too. We should be allowed to be proud and say, "we're English”.

I So if the parliament's that's in London became just an English one and dealt with English affairs, that would be OK?

AD Yeah. Well, that's how it should be.

From this vantage point, the value of national self-determination as a political end in its own right could be understood even to trump concerns over England's material interests:

I What about Scottish independence?

LM Well, I don't think that they need much from us do they? What can we offer the Scots?

I What about England? Would we lose out? 
LM Almost certainly we'd be worse off. But all countries should be independent. Home Rule.

The adoption of Popular Nationalism as a general frame of political reference did not automatically determine the bottom-line position that a speaker adopted towards specific policy issues. For example, although respondents could invoke values of political nationalism to support arguments in favour of the symmetrical treatment of England and Scotland, they did not always do so. In the next extract we see a case where the respondent treats national self-governance as right in principle, but contrasts the pragmatic implications for Scotland with the likely consequences for England where the existence of a national parliament might paradoxically militate against the ultimate goal of national sovereignty:

I Some people have suggested that one of the ways to go for devolution, is to have an English parliament, you know Scotland's got theirs and the Welsh have got theirs, would you want to see that?

HK Assuming that the changes we've got are irreversible, and it seems only fair that from an equitable stand point that yeah if you are going to go and have a Welsh assembly and a Scottish Parliament that they should in fact be something that was going to go and provide a sounding board for the English. But, that said, I am not pro-European. So to that extent I am not anxious to go and see an English parliament. Because I think it would be so much easier for them to go and slide us into a region of Europe and nothing could be said about it. And to that extent, even though I can see it's unfair, I suppose if it came to a referendum I wouldn't in fact, go and vote for an English parliament. 


\section{Localism.}

Localite (cf. Merton, 1957) accounts tended to be used by people with little formal education and relatively little experience of geographical mobility. These respondents tended to be politically disengaged, and to possess only the most basic understanding of the process of UK constitutional change.

The main distinguishing feature of Localism discourses was, as the label suggests, that the speaker displayed a primary concern for issues understood to be personal, concrete and close to home, and displayed little interest in matters understood to be remote, generic or abstract. A concern for the personal and the local could also be evident in Popular Nationalism accounts. However, in this case, the speaker tended to elide the local with the national, and to treat their personal experiences, social networks and local area of residence as exemplifications of the generic construct of Englishness (cf. Cohen’s, 1996 construct of personal nationalism). In contrast, respondents who adopted Localism repertoires tended to treat nationality in general, and Englishness in particular, as experience-distant constructs. In consequence, interviewers could experience great difficulty in eliciting conversation about the respondents' views concerning national issues, and about their personal sense of national identity ${ }^{\text {ix }}$.

Localite accounts rarely associated English national identity with entitlement to political voice. However, to put this in context, these respondents were generally disinclined to claim political voice on the basis of any abstract category membership. Some respondents made a positive claim to political apathy, and adopted a don't know/don’t care position in relation to devolution:

EV Well to be honest I'd have to say I don't [care about the Scottish Parliament]. The point is I'm not interested in politics. But in saying that everybody should 
get their own say [...] So if they want to have their own government it's entirely up to them. It's no skin off my nose.

I Would you want to see an English one? If Scotland's got their's would you want an English one to just look after England?

EV Just England itself. I'm not particularly worried because again you're talking about politics and politics is one thing I'm not interested in [...] There's certain people who come [into the Pub] and they blab on about politics but they turn round to me and they try and get me involved. And if I say something offhand and they say, "well if you don't vote what are you saying then?" And I say "Well I'm only saying it because you asked me" and I just, you know, it's just to pass conversation. I mean, I've even told them they are all as bad as one another. And they say, "how do you know unless you voted?". Let's put it this way, all right I've never voted in my life, let's just say it was a tie, let's just say it was a tie right. Are they gonna come and ask me?

Other respondents adopting a Localite stance claimed a positive attitude towards The Scottish Parliament. However, since the speakers typically possessed very little information about the devolution process, in practice these opinions typically took the form of 'non-attitudes', lacking any meaningful issue-content (cf. Converse, 1964). When asked to explain their views, respondents were inclined to produce minimal arguments ('why not?’), which typically rested on a banal (Billig, 1995) presumption concerning the legitimacy of national self-determination:

MH Yeah, because they've got issues that we don't have, and only Scottish people would know what to do about it. I mean, they know their country just as much as we know ours. So, why shouldn't they?

I Do you think there are issues then that are English issues or Scottish issues, that aren't British issues if that makes sense?

MH There must be, otherwise they wouldn't want their own government. ((laughter)). 
Whereas people adopting a Popular Nationalism frame could extemporise around core beliefs concerning the value of national self-determination, people adopting Localism discourses were rarely able to discuss their endorsement of nationalist politics as a matter of abstract principle, or to maintain an extended line of political argument:

I [...] Are you interested in devolution in Britain, does it interest you?

LA Yeah. Yeah. It does. Yeah.

I In what way?

LA I think erm, yeah, because, well, the way it interests me is because they should have their own parliaments, because they are separate from us.

I Mm.

LA And, I mean, the Scottish, they are separate from us, the Irish are separate, separated from us, they are different countries even though, you know, all the history about it, you can say Okay, you know, that's not quite the case, but they are, and I think, Yes, they should have their own parliaments.

I Do you think that will have any effect upon this country?

LA Ooh.

I In giving people these different parliaments?

LA Why not? Possibly.

I What do you think the effect might be?

LA Ooh, goodness. Politics.

I Well, it's not really politics.

LA Well, I mean, I think it will have an effect, like, because things we do erm it will have an effect because- because of- stop the tape. I'm stuck ((laughter)).

\section{Reasonable Pragmatism.}

This analytic category embraces a range of arguments concerning devolved governance adopted by people from a variety of different backgrounds and mainstream party-political affiliations. The fact that the research sample was not representative in a statistical sense precludes precise estimates concerning the relative 
distribution of particular styles of argument. However, previous research suggests that the kinds of accounts that I am classifying as examples of Reasonable Pragmatism tend to represent the most common kind of position adopted towards matters of nationhood and national identity in England (Condor, 1996; 2000; 2006; Condor \& Abell, 2006).

The styles of argument included in this category are reasonable in Sibley's (1953) sense of displaying a willingness to adopt a common standpoint and to evaluate political issues in the light of the interests of others. They are pragmatic in the sense of demonstrating a preparedness of compromise in the interests of social harmony and political moderation. Significantly, respondents who adopted a stance of Reasonable Pragmatism were inclined to position their views in direct opposition to the confrontational discourse of Popular Nationalism.

In the course of discussion, speakers adopting Reasonable Pragmatist stances generally evidenced concern for normative virtues of liberal democratic citizenship and values of pluralism. This often entailed a general suspicion of explicit invocations of nationalism and strong public claims to national identity, which tended to be regarded as antithetical to values of individualism, universalism and civility. Respondents adopting a Reasonable Pragmatist perspective could describe their own sense of national identity in a variety of ways. However, they tended to orient to a common set of normative considerations in the course of claiming, or disclaiming, a particular sense of national identity. Specifically, these respondents were inclined to treat public claims to national identity as a communicative act that needed to be managed in the light of the sensitivities and interests of others.

From the vantage point of Reasonable Pragmatism, respondents could assemble a variety of different lines of argument concerning devolved governance. 
For example, when discussing the Scottish Parliament or the prospect of Scottish independence they could adopt a position of principled agnosticism ('It's not for me to say’). Alternatively they could express positive views concerning Scottish devolution ('I think it's great') justified with reference to the rights of Scottish people as free and equal citizens. Finally, they could adopt a position of detached acceptance, typically justified with reference to values of toleration of diversity.

Respondents often displayed their commitment to Reasonable Pragmatism through the expression of empathy with the populations of Wales and Scotland, in conjunction with the adoption of a general air of rational disinterest:

ML: Yeah [devolution is] OK. It doesn’t particularly concern me.

RL: I mean it's - I don't think it's been in the news as much as it was when it first all happened. When devolution first happened.

ML: You don't hear much about it do you really?

RL: You do get the odd thing. Especially around election time when you've obviously got Scottish Nationalists and the Welsh Nationalists competing for the seats.

I: $\quad$ And what are your views on that? Are you fine with it or -?

ML: Yeah.

RL: $\quad$ Don't mind.

ML: I can understand it. If I Welsh, I'd probably be, supporting Plaid Cymru and you know.

I: What were your thoughts at the time the Scottish Parliament was set up?

RL: I didn’t - no I didn’t feel strongly about it. No. I mean even before devolution [Scotland] had some different laws and things anyway didn’t it?

ML: Well yes, different education system.

RL: Yes.

ML: Which is apparently better than the English one, you know. 
RL: Yeah, it's why not, if they want -so I don't know. I just feel like that really, I think. It's up to them. I don't mind either way.

ML: Yeah, I agree with you.

RL: They've been dominated politically and culturally by England for so long. If they want some independence that's up to them. I can understand it. And you only have to look at what happened in Northern Ireland to see- to see what happens when you try to force a political system on people who don't want it.

I: What would your thoughts be on the possibility of an English Parliament in a similar vein to the Scottish Parliament?

RL: I think it's just complicating what we've got really. Cos I think our Parliament is more English than anything else, don't you? More London than anything else isn't it?

ML: Yes it would be redundant really wouldn’t it? Not necessary.

Significantly, Reasonable Pragmatist discourses tended to cast political fairness as a matter of equity. From this perspective, the asymmetric character of the devolution settlement could be understood to represent an eminently 'fair' arrangement. Respondents who voiced support for the Scottish Parliament could reasonably oppose the idea of an English parliament in a number of ways. They could refer to differences between the two national cultures noting, for example, that people in England were 'not as nationalistic' as the Scots. Respondents could also allude to pragmatic concerns relating to the relative political needs of the two countries. As Beiner (2004) notes, arguments concerning identity-based rights tend, by their very nature, to be non-symmetrical. Respondents adopting a Reasonable Pragmatist position often treated the establishment of the Scottish Parliament as a matter of 'minority rights' that, by definition, could not reasonably be applied to England:

I What about the idea of an English parliament?

$[\ldots]$

CJ Erm. I dunno, I don't actually care. I don't think it's actually hurting 
England at the moment, not to have their own parliament [...] I don't think we have to do that yet. That may come, it may come, but I think that's divisive, I think the Scots have got enough, have suffered enough, to feel resentful. I think they're quite justified in hating our guts, yeah? But I don't think the English are justified in hating the Scots' guts because we've had most of the resources. I think they have come off worse, and so's Wales.

Consequently, whereas Scottish identity could be treated as a legitimate basis for claiming political entitlements, English identity was understood to normatively entail the acceptance of political responsibilities (cf. Williams, 2008), displayed through the use of public reason (cf. Rawls, 1996) as opposed to appeals to rational self-interest:

I So, what do you think about Scotland having its own parliament?

PP It's fine. They had a referendum and that's what they wanted. I'm not sure why they wanted it mind ((laugh)) but there's no reason why they shouldn't as far as I can see.

I Do you think that it's likely to have any effect on people in England?

PP Hm I shouldn't think so but I don't know that much about it as you might be able to tell. Um but something I do get a bit concerned about is that mentality you know people who are always judging things in terms of what's in it for England and sod anyone else and you know the kind of anorak who goes about spouting all this esoteric information you know sits in the pub sounding off - of course for all I know it might well be true but you know bores you to death with all the facts and figures and wherever I hear an English person starting to spout all the facts and figures, you know, "Scotland gets this, England doesn't have that” all that sort of thing my heckles start to rise I Yeah?

PP Yeah. I don't know why some people get so het up, why they can't just y’know mind their own business. Live and let live. 


\section{Liberal Cosmopolitanism.}

Arguments classified as examples of Liberal Cosmopolitanism were distinguished by their explicit rejection of political Nationalism. This position was also associated with an opposition to ethnic constructions of nationhood, and a strong endorsement of the fact and value of multiculturalism. The respondents who used this frame of reference tended to be highly educated, and to claim Left-of-Centre political sympathies.

On occasions, respondents adopting a Liberal Cosmopolitan stance could attempt to voice symmetrical arguments, in which anti-nationalist political values were applied equally to Scotland and to England. This could lead them to express scepticism of, and very occasionally, outright objections to the Scottish Parliament as a nationally defined polity. However, in these instances respondents typically found themselves in an ambivalent situation in the light of a perceived normative requirement to respect the Scots' minority national status. One way in which respondents attempted to manage this dilemma was by using class-based considerations to trump the suspect classification of national identity. In the next extract we see one respondent who is adopting a Liberal Cosmopolitan frame attempt to argue her case against another $(\mathrm{JJ})$ who is adopting a Reasonable Pragmatist position:

NM I just don't like this closed nationalism, basically, I don't think people should be defined by national groups, and I don't agree that, that the Scots do it, or other countries. [...]

JJ Maybe it is, but I can still see where they're coming from when they

NM Well, to my mind,

JJ get upset about it.

NM it's most of my ancestors probably, who were English, but they were poor English, mostly. And I don't see the difference, really. 
JJ I'm not saying the Scottish are right to be upset about it, I'm saying I can understand why they are.

Respondents adopting a Liberal Cosmopolitan perspective were typically inclined to regard Nationalism as an atavistic form of ideology and political organization (see also Condor, 2006). Accordingly, they could avoid casting judgement on the nationally defined Scottish Parliament by treating it as a functional irrelevance in the light of the inexorable tide of utopian post-national historical progress:

MS [...] when you think of it the idea of an autonomous Scottish Parliament or a Scottish legal system come to that has a restricted shelf life given that in a few years hopefully we'll all be European anyway.

Another strategy used by respondents who voiced opposition to the principle of political nationalism was to employ non-symmetrical normative arguments, according to which the Scottish Parliament was supported with reference to generic values of rights to self-determination, but the prospect of English national self-governance rejected on the grounds of universal principles of anti-nationalism.

For example, in the first of the following extracts the speaker is responding to a question concerning his views on the Scottish Parliament:

GC $[\ldots]$ if that's the way they want to go that's democracy, then that's it, isn't it? You have to go with the masses. But there's nothing I can do about it.

The interviewer then follows this up with a question concerning his views on an English parliament:

I: Would you want to see devolution for here then? Would you want to see an English parliament?

GC Not really 
I: Why not? Everybody else gets theirs. Why not?

GC Well, cause two wrongs don't make a right do they?

Finally, some respondents managed the difficult situation of balancing a recognition of Scottish minority rights with universal values of anti-nationalism by adopting what effectively constituted an 'exit' strategy. Assuming a position of moral relativity, they advocated leaving the Scots to their nationalism and, somewhat paradoxically, advocating Scottish independence as a means by which they, as English, could maintain an ideological commitment to cosmopolitanism:

PO I got to the stage a while ago when I just thought, this is getting really boring. At first when there was the Scottish Parliament and you got those surveys on ‘are you English or are you British’ or whatever, you thought, yeah, $\mathrm{OK}$, and some of it was even mildly amusing. But now it's not just a bit of a joke, it's getting REALLY irritating. It's an indulgence. It's a distraction from all the important things going on. There’s Zimbabwe. There's Iraq. There's all these terrible things. There's people starving there's children dying. And there's the European Union but no, that's not important. What's important is whether you call yourself English or bloody British. Does anyone really give a fuck? I'm fed up with having to listen to Scottish politicians on the media going on about England this, nation that, Scotland the other. I just wish that Scotland would bloody well hurry up and become independent so that everyone would shut up and people would stop doing all of this stupid research about national bloody identity.

\section{Concluding Comments.}

Since the alarm was first raised concerning the impending English reaction to the Scotland Act, false sightings of an English backlash on the political horizon have become a regular feature of media reports on matters relating to devolved governance. Recent examples include a feature in the Scotsman reported under the heading, MPs 
warn of English backlash over Scots' votes in Commons ${ }^{\mathrm{x}}$, and a report in the Daily Express concerning English resentment over higher levels of Scottish public expenditure: 'A growing backlash against Scots among the English is leading to the break-up of the $U K^{\text {,xi }}$. However, whilst issues relating to the devolution settlement clearly continue to excite media commentators, politicians and academics, ordinary English people by and large remain stubbornly galvanized into inaction.

An examination of the way in which social actors in England currently understand, and reason about, the process of constitutional change alerts us to the fact that political disengagement may take a variety of forms. Many of the people who took part in the research displayed an apathetic lack of concern about past and prospective changes to the UK constitution. For other people, disengagement was effected through an active avoidance of what they understood to be an inherently dilemmatic political situation, in which their opposition to the establishment of nationally defined polities clashed with their support for the principle of national minority rights. For the majority, disengagement took the form of principled agnosticism or passive acquiesce based on the view that the new political status quo represented the legitimate political will of the Scottish people.

An appreciation of the internal logic of everyday political reasoning in England also can help us to understand why the asymmetric character of the devolution settlement has not yet provoked energetic public resentment. In the first place, people in England are often still unaware of the policy issues that excite so much interest amongst the political and intellectual elite. Secondly, people in England are generally disinclined to evaluate the devolution settlement on the basis of calculations of English national self-interest, or in relation to concerns about substantive equality between England and Scotland. Rather, attitudes towards the 
Scottish Parliament, an English Parliament or Scottish independence tend to be formulated in the light of concerns over equity and procedural justice.

Finally, this research suggests that the relationship between constitutional attitudes and English national identity is rather more subtle than is often supposed. There was no evidence to support the common contention that people in England simply fail to recognize themselves as English. In addition, whether an individual chose to define themselves as English or British or both or neither generally had little direct bearing upon the position they adopted concerning the Scottish Parliament, or concerning the possibility of Scottish independence or English self-governance. Hence, rather than consider whether a social actor's sense of national identity relates to their attitudes concerning devolved governance, it may be more enlightening to ask how people understand their status as English to bear upon their views concerning constitutional politics. The basic finding to emerge from this research was that people in England do not currently accept asymmetric devolution because they lack a sense of English identity. On the contrary, most people view active engagement - and especially critical engagement - with the new political status quo as precisely incompatible with the normative requirements of public reason and civic responsibility incumbent upon themselves as members of the English majority. 
References.

Aughey, A. (2007) The Politics of Englishness. Manchester: MUP.

Beiner, R. (2003) Liberalism, Nationalism, Citizenship. Vancouver: UBC Press.

Billig, M. (1995) Banal Nationalism. London: Sage.

Bogdanor, V. (2005) Devolution and the territorial constitution http://www.gresham.ac.uk/event.asp?PageId=39\&EventId=281.

Bryant, C. (2008) Devolution, equity and the English question. Nations and Nationalism, 14, 664-683.

Cohen, A.P. (1996) Personal nationalism. American Ethnologist, 23, 802-815.

Condor, S. (1996) Unimagined community? Some social psychological issues concerning English national identity. In, G. Breakwell and E. Lyons (eds) Changing European Identities. Oxford: Butterworth Heinemann.

Condor, S. (2006). Temporality and collectivity: Diversity, history and the rhetorical construction of national entitativity. British Journal of Social Psychology, 45, 657-682.

Condor, S. (2000) Pride and prejudice: Identity management in English people's talk about "this country". Discourse and Society, 11, 163-193.

Condor, S. \& Abell, J. (2006). Vernacular accounts of 'national identity' in postdevolution Scotland and England. In, J. Wilson, J. \& K. Stapleton (Eds). Devolution and Identity. Aldershot: Ashgate.

Condor, S. \& Gibson, S. (2007) 'Everybody’s entitled to their own opinion’: Ideological dilemmas of liberal individualism and active citizenship. Journal of Community and Applied Social Psychology, 6, 178-199

Converse, P.E. (1964) The nature of belief systems in mass publics. In, D.E, Apter (Ed) Ideology and Discontent. London: Collier-Macmillan (pp. 206-261). 
Curtice, J. (2003) Devolution, the Union and Public Opinion. Hansard House of Lords Second Report on the Constitution, Appendix 5.

Curtice, J. (2006) A Stronger or Weaker Union? Public Reactions to Asymmetric Devolution in the United Kingdom. Publius, 36, 95-113.

Curtice, J. \& Heath, A. (2000) Is the English lion about to roar? National identity after devolution. In, R. Jowell, J. Curtice, A. Park, K. Thomson, L. Jarvis, C. Bromley \& N. Stratford (eds) British Social Attitudes: the 17th reportFocusing on diversity. London: Sage.

Curtice, J. and Seyd, B. (2001) Is devolution strengthening or weakening the UK? In, A. Park, J. Curtice, K. Thomson, L. Jarvis, and C. Bromley, C. (eds.) British Social Attitudes: the 18th Report. London, Sage.

Curtice, J. \& Sandford. M. (2004) Does England want devolution too? In, A. Park, J. Curtice, K. Thomson, C. Bromley \& M. Phillips (Eds) British Social Attitudes: the $21^{\text {st }}$ Report. London: Sage.

Eliasoph, N. (1998) Avoiding Politics: How Americans produce apathy in everyday life. New York: Cambridge University Press.

Heath, A., Rothon, C. \& Jarvis, L. (2002) English to the core? In, A. Park, J. Curtice, K. Thomson, L. Jarvis and C. Bromley (Eds) British Social Attitudes: The 19th Report. London: Sage.

Kazin, M (1998) The Popularist Persuasion. Cornell University Press.

Lane, R.E. (1962) Political Ideology. New York: Free Press.

Merton, R. (1957) Social Theory and Social Structure. Glencoe IL: Free Press.

Rawls, J. (1996) Political Liberalism. $2^{\text {nd }}$ edition. New York: CUP.

Sibley, W.M. (1953) The rational versus the reasonable. Philosophical Review, 62, 554-60. 
Devolution and English identity 31

Williams, G. (2008) Responsibility as a virtue. Ethical Theory and Moral Practice, $11,455-470$ 
Notes

i 17 June 1998, Hansard Lords Debates: Columns 1654-1655.

ii 12 Jan 1998, Hansard: Columns 89-90

iii The Guardian Unlimited, April 18, 1999.

iv The original transcripts record the conversations completely verbatim. However, since this article focuses on the substance of a speaker's argument, I have simplified some of the extracts to facilitate readability.

${ }^{\mathrm{v}}$ The Migrants and Nationals project conducted with David McCrone, Frank Bechhofer and Richard Kiely at the University of Edinburgh and Jackie Abell, Clifford Stevenson and Stephen Gibson at Lancaster University. The project was funded the Leverhulme Trust within the Constitutional Change and Identity programme grant (award number: 35113).

${ }^{\text {vi }}$ Since respondents typically displayed little awareness of proposals for English regional governance, the following account will focus on respondents' views concerning the Scottish Parliament, the prospect of Scottish political independence, and the possibility of a separate English parliament.

vii These labels are intended to describe the way in which the respondent positioned themselves and their argument in national/political space, and are not intended to imply an evaluative judgement.

viii This typography pertains to lines of argument, rather than to positions reliably adopted by individual speakers. However, although individual respondents did not always produce arguments that fell squarely into one particular category, it was in practice very rare for any respondent to employ lines of argument belonging to nonadjacent categories.

ix These respondents sometimes displayed problems differentiating the constructs of English and British. They were the only group to do so.

x $19^{\text {th }}$ June 2006.

${ }^{\mathrm{xi}} 25^{\text {th }}$ February, 2008. 